\title{
The Determinants of Entrepreneurial Act in the Moroccan Textile Sector: A Logistic Regression Approach
}

\author{
Omar TAOUAB \\ Dept. of Management, Ibn Tofail University \\ PO Box 2010, Kenitra, Maroc \\ Tel: 212-661-965-962Ｅ-mail: taouabomar@yahoo.fr
}

Received: January 10, 2014 Accepted: February 15, 2014 Published: March 19, 2014

doi:10.5296/bmh.v2i1.5317 URL: http://dx.doi.org/10.5296/bmh.v2i1.5317

\begin{abstract}
Entrepreneurship and business creation is a key factor to enhance the vitality and development of the Moroccan economy especially when undertaken in areas of high economic impact including the textile sector.

To delineate the main determinants of entrepreneurial activity factors, we mobilized the theoretical model of planned behavior (Ajzen \& Fishbein, 1991), and the model of Shapero (1993) who consider the desirability of the act of undertake as a dependent variable of demographic variables and personality traits. Our results have directed us to the proposal of some actions to be taken to increase the likelihood of undertaking in this area. Each proposed action is accompanied by an approximation of the expected positive effects on endogenous variable due to a variation of a factor
\end{abstract}

Keywords: Entrepreneurship Intention, desirability, feasibility, model logit 


\section{Introduction}

The discipline of entrepreneurship is a relatively new area of research. Indeed, management research in Morocco has started in the 90s of the last century (Ahsina 2012), hence the interest of this research.

Entrepreneurship is a major goal and issue for many countries, particularly those in developing countries, especially when it comes to capital holder's month such as textile sectors. This sector creates ample among different actors. Such a growing interest is justified in part by its contribution to the job, the creation of added value and secondly, through its participation in the improvement of the trade balance balances.

Such attention turned to entrepreneurship in this sector is evident through several actions and advantages enjoyed by operators. It is, as an indication of the program contract, the granting of tax exemptions in the Value Added Tax and other social and economic incentives. Nevertheless, despite these attentions and interests for this sector,

Entrepreneurial actions in recent years have significantly decreased and going against the expectations and objectives of economic policy. From this observation, it seemed interesting to study the various factors and explanatory variables as the intention of entrepreneurial achievement with a population of entrepreneurs in the sector.

The majority of theoretical works that focus on the study of entrepreneurial intentions are based on the theory of planned behavior (TPB) (Ajzen, 1991) and the model of the entrepreneurial event (Shapero \& Sokol, 1982; Krueger et al., 2000; Emin, 2003; Boissin et al., 2005; Fayolle, 2005; Fayolle et al., 2006; Kolvereid \& Isaksen, 2006; Souitaris et al., 2007). These procedures provide a similar explanation of entrepreneurial intention of the individual and provide a coherent framework, simple and robust to achieve a better understanding of the process of business creation (Krueger et al., 2000). Similarly, this framework allows us to highlight the main determinants influencing the passage of the desirability to realization of the intention to undertake in following the model of the entrepreneurial event (Schapero, 1982).

The evaluation of the impact of different variables mentioned by the theoretical framework can be done through the use of an empirical test. Such a test makes use of a well-specified and dedicated to the estimation of the coefficients of structural equations involving qualitative variables including the desirability and feasibility of entrepreneurial econometric model. These coefficients are we of assessment tools and interpretation both in the sense of connection and that the magnitude of the impact.

To carry out this test, we propose to present this paper as follows:

In the first section we present the theoretical aspects of entrepreneurial intention and its feasibility. In a second, the research methodology will be exposed to lead on a presentation of the different results in the third section matching suggestions and proposals. 


\section{Theoretical Frameworks}

We start with the presentation of the theory of planned behavior (Ajzen, 1991) and then we link the model of the entrepreneurial event Schapiro.

\subsection{The Theory of Planned Behavior (Ajzen, 1991)}

The theory of planned behavior gives the intention of the individual the central square of the genesis of behavior (Tounès, 2003; Fayolle et al., 2006). According to this theory, any behavior that requires some planning (such as starting a business), can be predicted by the intention to have this behavior. The advantage of this theory is to propose a theoretical model used in all situations where the behavior is intentional since it does not rely on external variables such as proximate determinants of behavior (Emin, 2003). According to the theory of planned behavior (Ajzen, 1991), the intention is the result of three conceptual determinants.

Behavior is determined by intention and perceived behavioral control.

\subsubsection{The Attitude against the Behavior}

The attitude against the behavior refers to the degree of favorable or unfavorable assessment a person has, the behavior in question (Ajzen, 1991). This variable represents the attractiveness of the behavior (Emin et al., 2005). For example, the attitude towards risk causes a person to consider positively or negatively the taking of risks. Same attitude towards success and failure of business creation promotes or disadvantage the decision to start a business in an individual.

\subsubsection{The Perceived Social Norm}

It refers to perceived social pressure to perform or not to perform a behavior (Ajzen, 1991). In other words, the perceived social norm is the perception of the individual to the social pressure regarding what close people, family and friends think it would take (Tounès, 2003; Fayolle et al., 2006). Attitudes against the behavior and social norms refer to the perceived desirability concept proposed by Shapero and Sokol (Tounès, 2003; Fayolle, 2005).

\subsubsection{Perceived Behavioral Control}

According to Ajzen (1991), perceived behavioral control is the perceived ease or difficulty to perform a behavior. For one, it refers to a person's perception of the feasibility of personal behavior concerned (Emin et al., 2005).

The concept of perceived behavioral control is very close to the concept of self-efficacy Bandura (1977) (Ajzen, 1991) and the concept of feasibility Shapero and Sokol (1982) (Tounès, 2003, Emin et al., 2005).

Attitudes vis-à-vis the behavior, perceived social norm and perceived behavioral control are expressed in terms of beliefs. These correspond to true or false information that a person has on the world around him. 


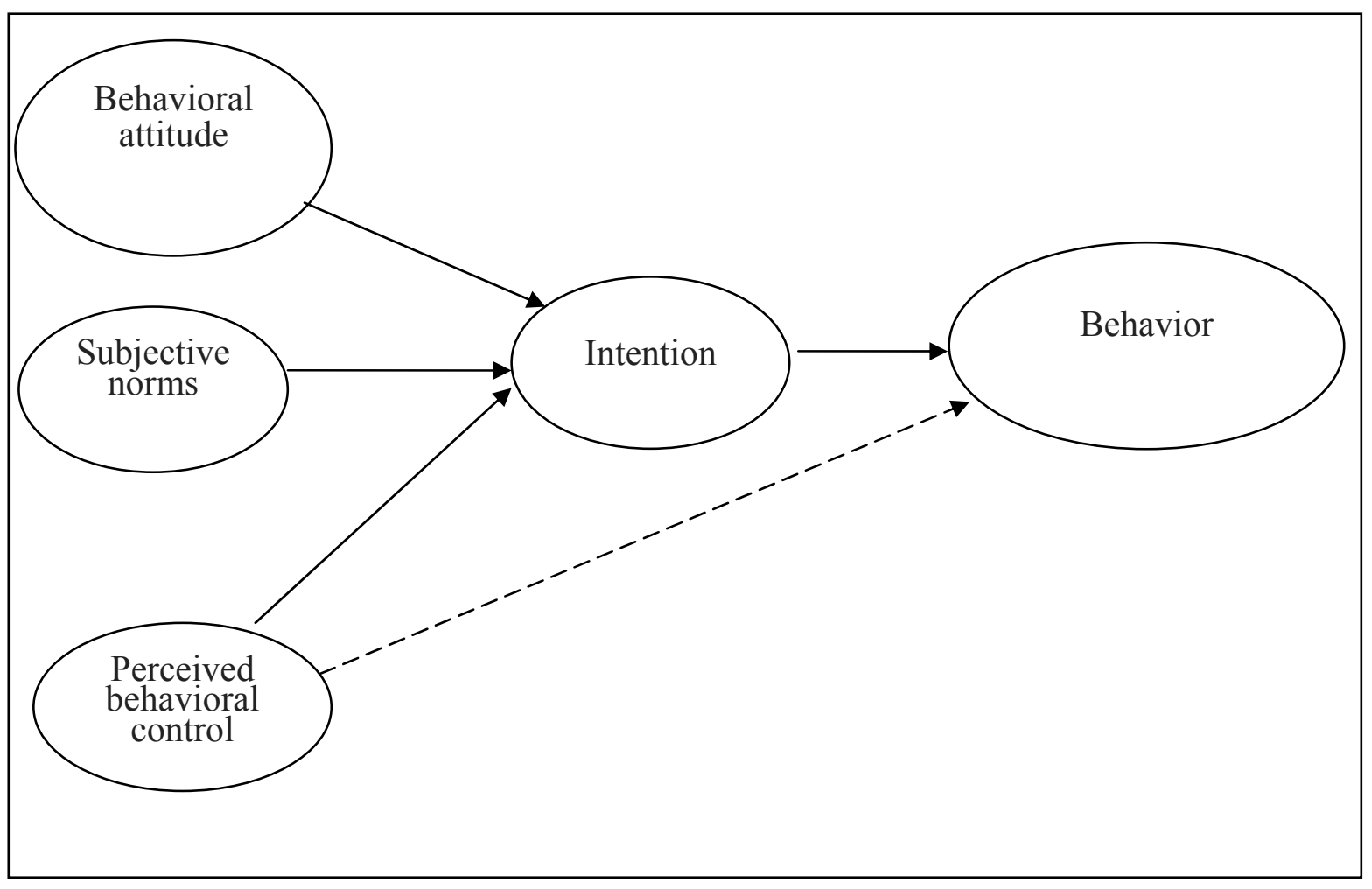

Figure 1. The model of the theory of planned behavior, Ajzen (1991)

\subsection{Schapero's Model}

Schapero's Model (Shapero \& Sokol, 1982) aims to explain the entrepreneurial event, that is to say, to study explanatory factors for the choice of entrepreneurship rather than another career path .

The entrepreneurial event results from the combination of four variables:

(1) A situation precipitating entrepreneurial act (negative displacement, positive or intermediate situation);

(2) Perceptions of desirability of the act (system of individual values);

(3) The feasibility of the measure (access to human and financial resources necessary technical) from the cultural, political, economic and social;

(4) Psychological disposition (propensity action).

Proposed by Shapero the model does not explicitly refer to the intention of creating a business. According to Krueger (1993) who offered a modernization of the formation of the entrepreneurial event that incorporates the concept of intention. It is represented in the figure below. In this model, the creator must first perceive the action of creating credible (i.e., they have entrepreneurial intentions) and then be encouraged to start really. Credibility based on the perceptions of feasibility and desirability and propensity to action that has a dampening 


\section{Macrothink}

effect. If we accept the propensity to action, two elements explain alone the intention of starting a business: the desirability of the act which reflects the attractiveness of the person for entrepreneurial behavior and the feasibility of the instrument that measures the perceived ease or difficulty that we think meet during the creative process.

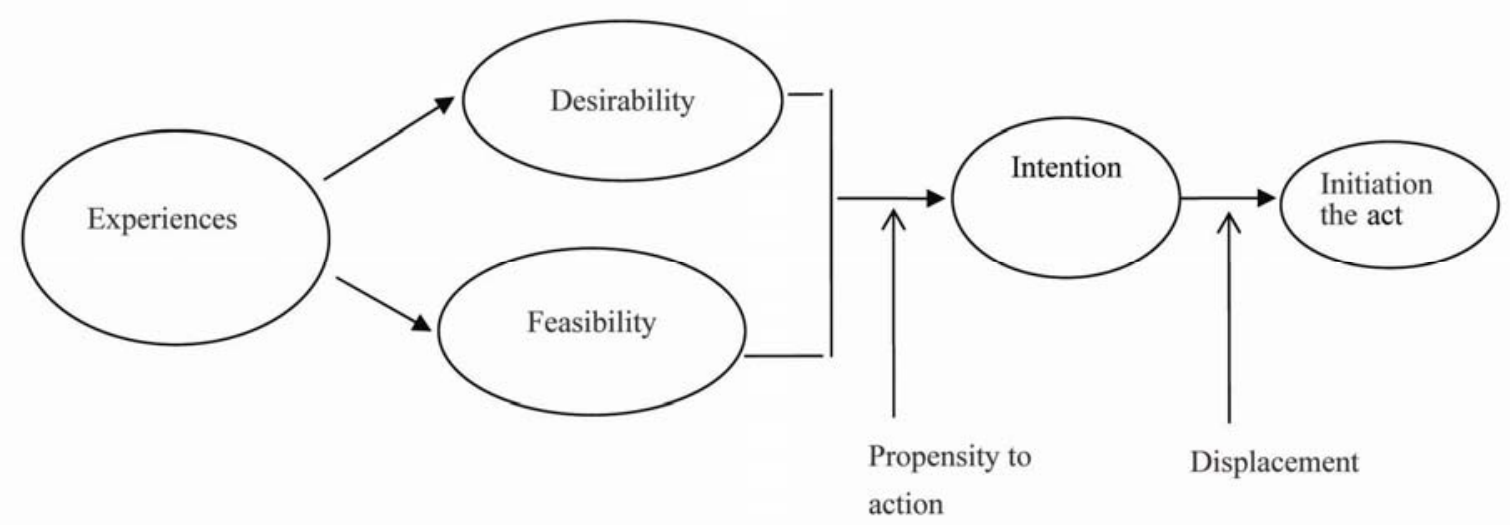

Figure 2. The Schapero and Sokol's model (1982)

\subsection{The Critical Variables Selected}

Theoretical reading of the various approaches has allowed us to identify some variables that may affect entrepreneurial intentions and condition the passage to the act of realization.

\subsubsection{Variables Derived from Ajzen Model}

Depending on the model of planned behavior, three variables are assumed to predict the intention of starting a business:

The attitude against the behavior expressed through:

- age,

- Sex,

- Education,

- Status.

The perceived social norm approximated by reviews:

- Friends,

- Parents,

- spouses.

The perceived behavioral control: 


\section{Macrothink}

Business and Management Horizons

ISSN 2326-0297

2014, Vol. 2, No. 1

According to Azjen (1991), perceived behavioral control measures the ease or difficulty that the creator sees potential for the realization of behavior. It is also defined as the perception of the presence or absence of requisite resources and opportunities.

\subsubsection{The Feasibility of Variable Schapero}

This variable approximates the feasibility of Schapero act of 1993 which is perceived by:

- Access to financial resources (financial availability: DF)

- Legal and tax incentives (FJF)

- Adequate performance (rate of segment performance: TRS)

\section{Research Methodology}

This section focuses on data collection, presentation variables and model specification.

\subsection{The Study Sample}

The sample, truncated, consists of 90 entrepreneurs from various industries sector belonging to three cities (Casablanca, Rabat and Salé). Of these respondents, $69.6 \%$ are men and $30.4 \%$ women.

\subsection{Data Collection}

The data collection tool that we used in this research is the questionnaire. For the development of the latter is referred to the definitions and descriptions of the different variables related by the theory of planned behavior and the event to begin. The questionnaire includes questions on the attitude against the business (attraction towards entrepreneurship), the perceived social norm, perceived behavioral control (perceived ability to create company), the intention to create a business and issues relating to the conditions of the realization of entrepreneurial intention.

\subsection{Model's Specification}

Rather than the probability of the dependent variable $\operatorname{Pr}(Y=1)$ varies linearly with $X$, we would like that $0 \leq \operatorname{Pr}(Y=1 \mid X) \leq 1$ for all values of $X$ and $\operatorname{Pr}(Y=1 \mid X)$ is an increasing function of $X$ for any $\beta 1>0$ ). To satisfy these constraints, only a non- linear function can fulfill these two conditions. The desired function likes an S-curve.

Two functions (among others) have the necessary characteristics: normal cumulative distribution function: the logistic model: logit and probit. In practice the two models give similar results.

$$
\operatorname{Pr}(Y=1 \mid X)=\operatorname{Pr}(Y=1 \mid X 1, X 2)=(\beta 0+\beta 1 X 1+\beta 2 X 2)=\Phi(\beta 0+\beta 1 X 1)
$$

\footnotetext{
$$
\beta_{0}+\beta_{1} X
$$$$
\Phi(\beta 0+\beta 1 X 1)=\int_{-\infty}(1 / \sqrt{ } 2 \Pi \Pi)^{*} \exp \left(-z^{2} / 2\right) d z
$$ 
Sometimes the $\beta 0+\beta 1 \mathrm{X}$ is known as $\mathrm{z}$-value or $\mathrm{z}$-index.

\section{Main Results of the Logistic Regression Analysis}

This section focuses on the presentation of the results of statistical tests and binary logistic regression.

\subsection{Results of the Statistical Analysis}

The statistics include the chi -square test and correlations were performed on SPSS 20 as binary logistic regression. In this context, the endogenous variable is entrepreneurial intention explained by:

- Attractive staff towards business creation approached by gender, status, age and education;

- The perceived social norm through the advice of parents, spouses and friends;

- Behavioral control via the ease or difficulty of achieving the intentions.

And feasibility of variable Schapero represented by:

- The financial availability (DF);

- Legal and tax incentives (FJF);

- The rate of return sector (TRS).

The test results will be presented by endogenous variable chosen according to whether the intention or entrepreneurial feasibility.

Regarding the intent, this variable must have clear correlations of $45 \%$ and $25 \%$ in $99 \%$ of cases with exogenous educations and status. Similarly, the Chi-square test (Table 1) allows us to admit the hypothesis of dependence between these variables in $99.4 \%$ of contingencies. However, other explanatory variables maintain a low correlation with the endogenous variable and exhibit collinearity which may bias the estimated coefficients of the structural equations.

Table 1. Feasibility test statistics

\begin{tabular}{lllll}
\hline & ACTE & DF & FJF & TRS \\
\hline Chi-Square $^{\mathrm{a}}$ & 1 & 6.25 & 9 & 9 \\
df & 1 & 1 & 1 & 1 \\
Asymp. Sig. & 0.317 & 0.01 & 0 & 0 \\
\hline
\end{tabular}

Note: ${ }^{\text {a }} 0$ cells $(0 \%)$ have expected frequencies less than 5.

The minimum expected cell frequency is 8.0.

The feasibility, availability of financial, legal and tax facilities as well as the floating rate segment performance showed their correlation with the variable realization of Schapero side. 


\section{Macrothink}

Indeed, these correlations are of the order of $60 \%, 54 \%$ and $30 \%$ respectively on DF, FJF and TRS and verifiable to a confidence level of $99 \%$. Dependence between feasibility and the explanatory variables is clearly apparent in $99 \%$ of cases.

The statistical analysis allows us to retain in the structural equations, variables that have links with the endogenous and a verifiable explanatory power.

\subsection{The Estimation Results of the Probit Model}

As we previously reported, according to the model of the theory of planned Ajzen (1991) behavior, entrepreneurial intention is conditioned by the personal attitude towards entrepreneurship (or attraction towards entrepreneurship), the perceived social norm and perceived behavioral control (or perceived ability to create a business).

In order to test the model of the theory of planned Ajzen (1991), we use binary logistic regression. Thus, the dependent variable is the entrepreneurial intention and the explanatory variables are respectively: the attitude towards business creation (attraction), perceived social norms (social) and perceived behavioral control (ability).

Table 2. Estimated coefficients in the equation "Intention"

\begin{tabular}{lllllll}
\hline variable & B & S.E & Wald & df & Sig & Exp(B) \\
\hline Education & 0.022 & 0.015 & 0.410 & 1 & 0.422 & 0.978 \\
Age & 0.012 & 0.006 & 3.762 & 1 & 0.052 & 0.988 \\
sex & 0.941 & 0.418 & 5.070 & 1 & 0.024 & 0.390 \\
status & 0.112 & 0.024 & 21.254 & 1 & 0.000 & 1.117 \\
Parent reviews & 1.053 & 0.381 & 7.637 & 1 & 0.006 & 2.866 \\
Perceived control & 0.289 & 0.527 & 0.301 & 1 & 0.583 & 1.336 \\
\hline
\end{tabular}

The results we obtained confirmed the validity of the theory of planned behavior in explaining the intention to create a business. Thus, the three explanatory variables significantly predicted entrepreneurial intention to varying degrees (Table 2). And the impact of staff perceived attractiveness through the status is $100 \%$ significant as the social norm through the advice of parents who approved its effect in $99.4 \%$ of cases. For cons, the personal control variable has no impact in $54 \%$ of cases and because of its collinearity with the variable status. 
Table 3. Estimated coefficients in the equation "feasibility"

\begin{tabular}{lllllll}
\hline variable & B & S.E & Wald & df & Sig & Exp(B) \\
\hline education & 0,016 & 0,024 & 0,037 & 1 & 0,543 & 1,015 \\
status & 0,151 & 0,080 & 3,577 & 1 & 0,059 & 0,860 \\
Parent reviews & 0,223 & 0,040 & 4,520 & 1 & 0,033 & 0,416 \\
DF & 0,113 & 0,096 & 1,375 & 1 & 0,241 & 1,120 \\
FJF & 0,105 & 0,103 & 1,040 & 1 & 0,308 & 0,901 \\
TRS & 0,122 & 0,104 & 1,387 & 1 & 0,239 & 0,885 \\
\hline
\end{tabular}

From the point of feasibility for the passage of the intention to carry out the project depends, according to the estimates (Table 3), the availability of financial resources, inherent sector legal and fiscal conditions and rates sector profitability respectively acceptance levels of $76 \%$, $70 \%$ and $77 \%$.

\section{Discussion and Suggestions}

Our results showed the relevance of the theory of planned behavior in explaining entrepreneurial intention. The model Ajzen (1991) has been validated and the three antecedents of entrepreneurial intention namely: personal attitude against entrepreneurship, perceived social norms and perceived behavioral control significantly predicted intends to establish a company in the textile sector.

In order to promote the development of the intention to undertake in future entrepreneur's policy makers can use the theory of planned Ajzen to better understand the motivations, beliefs and intentions of the individual behavior.

Order to change the entrepreneurial spirit among students, positive outreach initiatives against entrepreneurship may be incurred for the benefit of students of business schools, engineering and university. Indeed, teachers can conduct their courses testimonials from entrepreneurs. These can inspire and motivate students to choose the entrepreneurial career and incentives to excel in the development of best business plans and encourage them to realize their creative ideas.

To encourage entrepreneurship it is also important to take the cultural dimension. In this context, the media can play a significant role and presenting successful models of entrepreneurs and disseminate information on the positive role of entrepreneurship in society. The State may also intervene by presenting models and rewarding entrepreneurs by offering them prizes. This action is likely to recognize the public the importance of entrepreneurship in society.

The contribution of our research compared to the previous work on models for the validation consists of a positive impact of financial conditions and sector profitability.

Indeed, the Government may make the grant of tax exemptions in the main tax and taxes (the Income Tax, the Corporate Income Tax and Value Added Tax). As well as some reduction in 
payroll taxes include employer contributions to the National Social Security Fund, the medical insurance and other social security charges without omitting the preparation and flexible investment especially in terms of obtaining bank financing.

\section{References}

Ahsina K. (2012). Ten years of research in Accounting, Controlling and Audit in Morocco: a bibliographical approach. Kuwait Chapter of Arabian Journal of Business and Management Review, 1(11).

Ajzen, I. (2002). Perceived behavioural control, self-efficacy, locus of control, and the theory of planned behavior. Journal of Applied Social Psychology, 32(4), 665-683. http://dx.doi.org/10.1111/j.1559-1816.2002.tb00236.x

Boissin, J. P., \& Emin, S. (2006). Les étudiants et l'entrepreneuriat: l'effet des formations. Conférence internationale de management journal, Annecy/Genève.

Boissin, J. P., Chollet, B., \& Emin, S. (2005). Le faible attrait des étudiants pour l'entrepreneuriat-Eléments d'analyse pour l'action. Conférence de l'Association Internationale de Management Stratégique, 5-8 juin, Angers, France.

Boissin, J. P., Chollet, B., \& Emin. S. (2005). Les croyances des étudiants envers la création d'entreprise : un état de lieux. 4ème congres de l'académie de l'entrepreneuriat, Paris, 24-25.

Emin, S. (2003). L'intention de créer une entreprise des chercheurs publics: le cas français. Thèse pour le doctorat en sciences de gestion, Université Grenoble2, 447 pages.

Emin, S. (2006). La création d'entreprise: une perspective attractive pour les chercheurs publics? Revue Finance Contrôle Stratégie, 9(3), 39-65.

Fayolle, A., Gailly, B., \& Lassas-Clerc, N. (2006). Mesure de l'effet à court terme et à long terme d'un programme d'enseignement de l'entrepreneuriat (PEE) sur l'intention entrepreneuriale des participants: importance des conditions initiales. Actes du 8ème Congrès International Francophone en Entrepreneuriat et PME, Suisse.

Jarniou, C. L. (1999). Enseigner l'esprit d'entreprendre à des étudiants: réflexion autour d'une pratique de 10 ans. Actes du ler congrès de l'académie de l'entrepreneuriat, Lille.

Moreau. R. (2006). Quelle stabilité pour l'intention entrepreneuriale? Actes du 8ème Congrès International Francophone en Entrepreneuriat et PME, Suisse.

Tenenhaus, M. (2005). Régression logistique; application des modèles qualitatifs aux études sociologique.

Tounès, A. (2003). Une modélisation théorique de l'intention entrepreneuriale. Actes des VIIèmes journées scientifiques du réseau thématique de recherche en entrepreneuriat de l'A.U.F.

Tounès, A. (2006). L'intention entrepreneuriale des étudiants : le cas français. La Revue des Sciences de Gestion, n 219. 


\section{Macrothink}

Business and Management Horizons

ISSN 2326-0297

\section{Copyright Disclaimer}

Copyright reserved by the author(s).

This article is an open-access article distributed under the terms and conditions of the Creative Commons Attribution license (http://creativecommons.org/licenses/by/3.0/). 